\title{
Container barge (un)reliability in seaports: a company case study at the port of Antwerp
}

\section{Virzhiniia Oganesian*}

\author{
Ukrainian Sea Ports Authority, \\ Lanzheronovskaya 1, 65026 Odessa, Ukraine \\ Email: virginia.oganesian@uspa.gov.ua \\ *Corresponding author
}

\section{Christa Sys, Thierry Vanelslander and Edwin van Hassel}

\author{
University of Antwerp, \\ Prinsstraat 13, 2000 Antwerp, Belgium \\ Email: Christa.Sys@uantwerp.be \\ Email: Thierry.Vanelslander@uantwerp.be \\ Email: Edwin.vanhassel@uantwerp.be
}

\begin{abstract}
Inland waterways and ports play an important role in the entire transport system in the Hamburg-Le Havre range, and for the seaports of Antwerp and Rotterdam in particular. The high proportion of inland navigation for both ports can be explained by reasons such as an extensive network along with a safe, reliable, sustainable and cost efficient transport. However, despite all these advantages, container barge transportation still faces certain challenges. A major challenge relates to the unreliability of barge handling in large seaports, affecting overall performance of barge services essentially. This research shows that barge congestion exists, and it examines the causes of the observed phenomena. Next, it also provides an overview of solutions that are being developed in the port of Antwerp to improve and optimise container barge handling. Last, a case study is developed for a company that is located in the near proximity of the port of Antwerp, where the impact of barge handling unreliability is analysed.
\end{abstract}

Keywords: hinterland transport; inland navigation; inland port; container barge handling; supply chain.

Reference to this paper should be made as follows: Oganesian, V., Sys, C., Vanelslander, T. and van Hassel, E. (2021) 'Container barge (un)reliability in seaports: a company case study at the port of Antwerp', Int. J. Shipping and Transport Logistics, Vol. 13, No. 6, pp.624-648.

Biographical notes: Virzhiniia Oganesian graduated from Odessa National Maritime University in 2010 as a Master of Hydraulic Engineering with the right of performing general civil engineering works and started $\mathrm{PhD}$ researches in the field of Repair and Technical Operation of Maritime Transport Facilities. In 2016, she graduated from the University of Antwerp as an Advanced Master of Transport and Maritime Management. For two years, she had been working as a Junior Lecturer of Odessa State Academy of Technical Adjustment and Quality. Since 2013, she is working at Ukrainian Sea Ports Authority. She has 14 publications related to maritime transport and engineering field. 
Christa Sys is currently holder of the BNP Paribas Fortis Chair on Transport, Logistics and Ports at the Department of Transport and Regional Economics. Until October 2013, she was Scientific Director of the Research Centre on Freight and Passengers flows. Next, she is course coordinator for the courses Business Environment, Maritime Economics and Businesses and Maritime Supply Chain at the Centre for Maritime and Air Transport (C-MAT). She also teaches at the Faculty of Business and Economics. Her educational activities focus on (operational aspects of) maritime transport, transport economics and inland transportation. Her research centres on maritime economics and co-operation and competition in shipping.

Thierry Vanelslander is currently an Associate Professor at the Department of Transport and Regional Economics. He graduated as a Doctor in Applied Economics at the University of Antwerp. Until 2013, he was holder of the BNP Paribas Fortis chair on transport, logistics and ports. Until halfway 2009, he was Director of the Research Centre on Freight and Passenger Transport, hosted by the Department of Transport and Regional Economics. His research focuses on business economics in the port and maritime sector, and in land transport and urban logistics.

Edwin van Hassel (1981) is an Assistant Professor at the Faculty of Transport and Regional economics, Antwerp University and C-MAT where he is also teaching three courses. He has an Engineering degree in Naval Architecture and a $\mathrm{PhD}$ in Applied Economics. His main research interest and expertise is in inland navigation, port hinterland transport, ship design and transport modelling. More recently the scope of his work has been extended to maritime cost chain modelling. He also is involved in several researches ranging from logistics projects to infrastructure cost benefit analysis and transport modelling projects.

\section{Introduction}

Inland waterways and ports play an important role in the entire transport system in the Hamburg-Le Havre range, and for the seaports of Antwerp and Rotterdam in particular. In the modal split of both ports, the share of inland navigation accounts for $30 \%$ (Antwerp) and 40\% (Rotterdam) respectively in 2018. The high proportion of inland navigation in the port can be explained by reasons such as an extensive network along with a safe, reliable, sustainable and cost efficient transport. However, despite all these advantages, container barge transportation still faces certain challenges. Those challenges are not new, but were never empirically examined.

One of the challenges is the quality of barge handling in large seaports, affecting overall performance of barge services essentially. In 2015, inland navigation accounted for 1.89 million container movements in the Port of Antwerp; of which 1.37 million moves took place at the large maritime container terminals. One of the main issues is the insufficiently coordinated calls of barges to many terminals in seaports, next to the lack of a direct contractual relation between deeps terminal and barge operator, which leads to long waiting times, which affects reliability of deliveries significantly. This results in a decrease of productivity for the barge operator - which otherwise could use the time saved for sailing. In addition, this situation causes congestion and waiting times at terminals, because many barges call at the same terminal. Moreover, seagoing vessels 
also call at these terminals. These ships have priority over barges in handling, and hence the waiting time of barges increases. Furthermore, priority is also given to 'vletwerk' or intra-port moves between hub and deepsea terminal, followed by inland vessels operated on behalf of inland terminals often linked with deepsea terminals and finally tramp inland navigation. An additional problem is that when a delay arises at one terminal, the barge may not be on time for the agreed time window for handling at the next terminal. So, barge operators need to include large time margins when planning their terminal visits to ensure reliable transport services. This affects not only the productivity of the barge operators negatively, but also the deepsea terminal productivity, because the call size of these barges is generally small. This causes inefficiency of utilisation of port facilities, such as cranes, which are serving large vessels and are productive only due to the large-scale. Terminals have a structural problem with handling inland barges, given the absence of dedicated handling capacity of inland waterway transport. Additionally, too expensive ship to shore container cranes is used to handle the barges, which then again increases the costs.

In order to explore the problem of barge handling quality at large seaports, the paper focuses on the question what the transport-economic impact of barge (un)reliability at the port of Antwerp is for Umicore, a global materials technology and recycling group located in the close proximity of the port of Antwerp. Although literature has been occupied with this question, the topic has hardly been examined empirically.

The present paper explores the problem of barge handling quality at large seaports, specifically the port of Antwerp. To do this, the paper assesses the impact of (un)reliability of barge handling in the port of Antwerp on a shipper's business process (safety stock). Two research questions are proposed. The first research question is:

RQ1 Which actions have been taken in the port of Antwerp to improve barge handling reliability?

Next to this more general research question, which will provide an overview of the measures taken in the port of Antwerp, also a more detailed assessment will be made, at company level, to show how the barge unreliability impacts on shippers. The second question is:

RQ2 What is the transport-economic impact of this barge unreliability for a shipper in a company-specific case study?

This paper is structured as follows. First, Section 2 gives an overview of the problem of barge handling unreliability in the port of Antwerp. Section 3 reviews the scientific literature to have an idea which possible actions could be taken to overcome barge congestion in a deepsea port in general and at the port of Antwerp specifically. Section 4 presents the case study, including the methodology to quantify the transport-economic impact of barge unreliability, the data used and the results. Finally, conclusions are drawn in Section 5.

\section{Barge congestion in the port of Antwerp}

Container barging in the Hamburg-Le Havre range is of utmost importance for the seaports of Antwerp. This port, along with the port of Rotterdam, features the highest use of container barges among all ports in the Hamburg-Le Havre range. 
From the 2000 to 2018 there has been a strong increase in IWT volume coming to and from the port of Antwerp ( $+70 \%$ ). This gradual growth can be seen in Figure 1, where the strongest is observed in the period 2000 to 2008. In this period an increase of 14 million tonnes of containerised IWT cargo to 23.7 million tonnes can be observed. With an average payload of 10 tonnes per TEU is comparable to an increase of 0.98 million TEUs.

Figure 1 Growth of containerised IWT to and from the Port of Antwerp (see online version for colours)

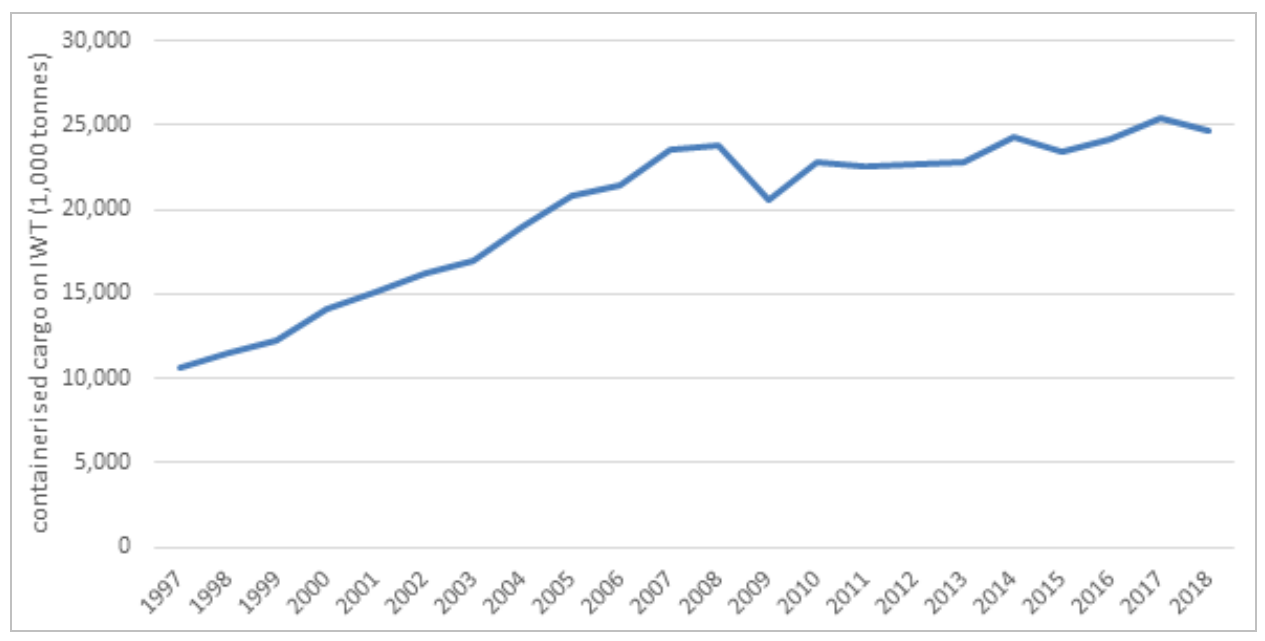

Source: Port of Antwerp (2019)

After the economic crisis 2008, there was a small decrease in IWT container traffic is observed. From 2010 onwards there is again an increase in container traffic observed, however, this time the growth is less strong then in the 2000-2008 period. In 2018 a total of 24.7 million tonnes (+/-2.47 million TEUs) of IWT container cargo was handled. This gradual growth in containerised cargo period also comes with operational challenges. The main challenge is to overcome the barge congestion problem in these specific seaports.

Container barges in particular will lose a lot of time in the seaport. As a result, the total transportation costs are increased due to the reduction in the economies of density. ${ }^{1}$ This affects not only the productivity of the barge operators negatively, but also the deepsea terminal productivity, because the call size of these barges is generally small. This causes inefficiency of utilisation of port facilities, such as cranes, which are serving large vessels and are productive only due to the large-scale, which is not applicable to barges (Visser et al., 2007).

Malchow (2014) argues that another problem with the inefficiencies of barge handling in large seaports is the fact that inland waterway vessels have to berth at the facilities, which are tailor-made for the biggest container vessels (with a capacity of $14,000 \mathrm{TEU}$ and even more). Hence, the efficiency of the big gantry cranes is not optimal when serving inland vessels.

Samuel (2019) shows that there is a barge congestion problem in Antwerp. Figure 2 shows the time profiles of barges visiting the Port of Antwerp, where the analysis is made on the total barge turnaround times in the port of Antwerp. The sample is based on 46 container barges that called at the Port of Antwerp between Q4 2017 and Q1 2019. 
Figure 1 shows that the average time spent by a barge at the port of Antwerp touched a peak of 28 hours per visit in Q4 2017, when the congestion problem was more pronounced. This number dropped from Q3 2018 onwards. To put these barge ration times into perspective Van der Horst (2016) noted that the total barge rotation time in Rotterdam (which has a similar barge congestion problem as Antwerp) was a decade ago estimated at 22.5 hours out of which 7.5 hours were used to load and unload while the remaining 15 hours were used in sailing and waiting to either be loaded or unloaded. The drop in the barge ration time in Antwerp (less congestion) could be the result of several digitalisation measures, which includes scheduling and capacity optimisations, which are applied at the port of Antwerp. In the next section, these different measures are explained and further explained and elaborated on.

Figure 2 Barge time profile at the Port of Antwerp (see online version for colours)

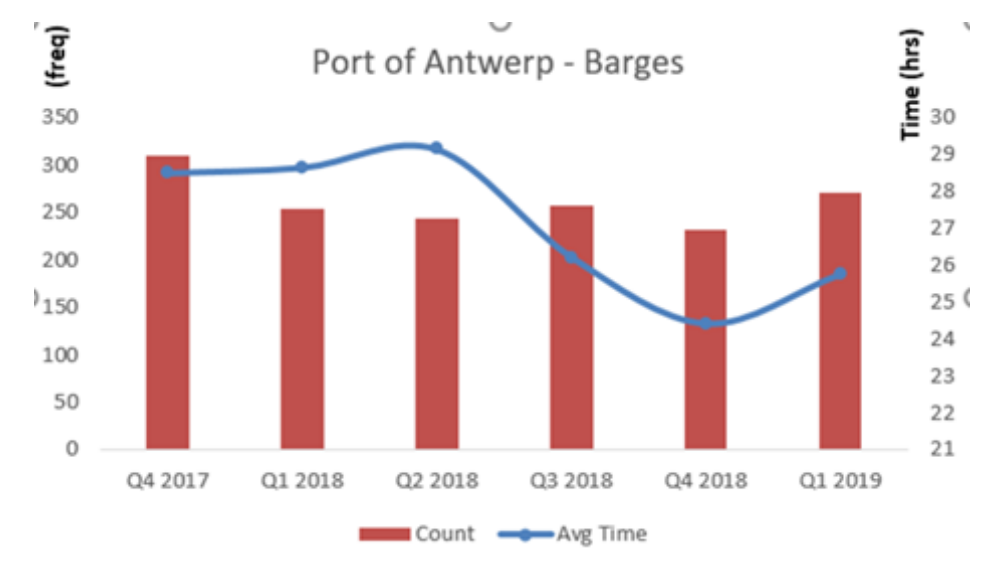

Source: Samuel (2019)

\section{Methods to improve and manage barge handling in a seaport}

In this section, first, an overview of the scientific literature is given with respect to developments to deal with the interaction between the deepsea terminal operators and the barges. Furthermore, the existing developments in the port of Antwerp are explained.

\subsection{Scientific literature}

Slack (1999) focuses on freight traffic, spatial externalities of intermodal freight business and congestion in hubs in Canada. The latter refers to so-called 'satellite terminals', which lays in the redevelopment of existing port sites and facilities in order to decrease pressure on big hubs in the long run. This model has some significant disadvantages, such as limited areas in ports, additional investments which mostly are applicable for port expansion strategies, and which require deep cost-benefit analysis for their implementation.

One of the first measures in this field was the applied method of rotation planning, helping to decrease the execution time for barge operations in ports, described by Schut et al. (2004) in the case of the port of Rotterdam. It was one of the attempts to automate 
planning between terminal and barge operators and to analyse the main reasons of delays and long waiting times at ports.

Visser et al. (2007) describe a concept of extended gateway of a modern port, which separates core activities of large terminals and additional services, shifting the latter ones towards the hinterland in order to reduce overloading and pressure at the port itself, and to avoid congestion, delays in services and waiting times for inland transport. This concept assumes a total division and separation of the container transhipment function from the container storage and sorting function, and to a certain extent coincides with Slack's idea of the creation of satellite terminals for similar functions. Visser et al. (2007) introduce the 'port entry' - the space, virtually shifted to an inland location.

Notteboom (2007) emphasises the need of creating dedicated barge terminals and load centres at the hinterland in order to remove the container-sorting function from the busiest port's terminals. It will not only give a possibility to provide more qualitative barge services and eliminate time losses, but it also enables seaports to take full advantage of the comparative advantages, while limiting the possible disadvantages of scale arising from the growing volume of maritime throughput.

In Konings (2007), the seminal work in cost analysis for inland navigation in ports, offers three basic service models, allowing the regularising of container collection at ports by splitting the existing operations into two parts: a trunk line part and a collection/distribution part. These models depend on the number of terminals in port, from where containers have to be collected, and the organisational structure of the collection/distribution transport. According to this, these are distinguished among by so-called 'container exchange points', 'barge service centres' and 'multi-hub terminals'. These models, from one side, provide savings gained from quick barge turnaround within the port or, from another side, may provide operational cost savings of collection/distribution of containers within port by means of internal transport (feeders, trucks, shuttles, etc.) (Konings, 2007).

The scale of the operations is an important factor. The deployment of large push-barges could also lead to cost reduction and a high level of fleet utilisation (Konings, 2009). The high level of automation, based on high-end technologies, is not novel, but proved itself as reliable and well-developed. By visiting a limited number of terminals and offering point-to-point services, push barges do not require quay-stacking facilities due to completely automated processes of loading/unloading by means of automated guided vehicles (Konings, 2009). Thus, all the processes of the Barge Express system are simultaneous and uninterrupted. In comparison with deepsea container handling terminals, due to absolute automation of the Barge Express system, the processes of planning and timing become much easier to manage and predict possible delays if they occur. Together with barge handling, these terminals may provide storage functions due to enough capacity.

Frémont et al. (2009) provide, from the perspective of theoretical and empirical analysis of the French inland waterways situation, an investigation of the entire European hinterland. The authors indicate the necessity of integration and close cooperation of barge carriers, terminal operators and road hauliers. In most cases, they act separately, and this separateness is the major obstacle to the development of competitive barge transport. Dissociation of service providers in inland transportation not only affects the entire barge chain with regard to managerial and planning tasks, but also has a great influence on the quality and transit timing of barge services. 
Caris et al. (2011) elaborate applied models based on several alternative hub scenarios in order to analyse and evaluate operational performances of the barge network in the port of Antwerp hinterland. Following Konings' ideas about container's pick up/drop off points, the authors developed some scenarios: creation of intermodal hubs on left and right banks of the river Scheldt and an improved multi-hub scenario specifically for the port of Antwerp. The central role in the study of Caris et al. (2011) is given to the freight bundling for generation of large aggregated cargo flows instead of small ones from each separated terminal. The findings are somewhat in line with those of Fattahi et al. (2016), who, be it in a more general logistics context, wider than inland navigation, look for a responsive and resilient supply chain network design under operational and disruption risks with delivery lead time sensitive customers.

Innovative concepts like the creation of automated barge terminals and floating container terminals, which could take over the collection and distribution of containers in the port from operators offering services between the port and the hinterland, are addressed in literature. An example of this is given in Malchow (2014) who proposes a port feeder barge (or floating terminal) as a possible solution to improve port handling efficiency and at the same time reduces the total port time of inland barges.

Furthermore, there are clear linkages with Marufuzzaman and Ekşioğlu (2016), who develop a MINLP model to help manage congestion in supply chains, which relies on using multiple transportation modes and multi-modal facilities for freight delivery. Their model captures the trade-offs between congestion and facility location; congestion and transportation mode selection; transportation network design and product seasonality.

Van der Horst (2016) further emphasised on the coordination issue by examining the hinterland chain of inland barging and major coordination problem of barge transportation. In this research three main coordination problems are discovered. Firstly, there is the issue the small call sizes from the barges and too many calls at different terminals leading to a high amount of time wasted in waiting time in the port. Better coordination and planning from barge operators could help reduce the number of calls. Secondly, there is the inadequate terminal and quay planning to handle barges. These first two coordination problems can be partially attributed to the lack of contractual relationship between the terminal operating companies and the barge operators. The barges are only scheduled and handled after the sea vessels have been attended to, hence passing any delay in handling the sea vessels down to the barges who have no influence on the terminal planning. Thirdly, there is the limited exchange of cargos. Exchange of cargos can bring about larger call sizes thus the use of bigger barge size which would lead to higher frequencies and fewer port calls. The main issue here is that barge owners are want to operate independently as a small scale company, leading to smaller quantities of cargos.

Kotowska et al. (2018) provide a general overview of the different measures that the port authorities of Antwerp, Rotterdam, Hamburg and Fos-Marseilles have taken to improve barge handling at the mentioned sea ports. These applications encompass a setup of different types of particular software/ICT platforms based on either geographic information systems (GIS), global positioning system (GPS) and other ICT to dedicated barge handling terminals (Rotterdam).

Shobayo and van Hassel (2019) investigate different options to reduce barge congestion. They concluded that investing in dedicated barge handling infrastructure is a more promising option to reduce barge congestion over more or better planning or coordination in barge handling in deepsea ports. The main difficulty with this solution is 
that there is the concern about who should bear the needed investments and how these cost and benefits can be distributed over the actors involved.

The next section will provide an overview of the existing application for the port of Antwerp.

\subsection{Existing real-life applications, focusing on the Port of Antwerp}

In order to manage and improve the logistics chain, from the hinterland to the deepsea terminal and vice versa, seven different applications are found which deal with the barge - port interactions in the port of Antwerp. In Figure 3, an overview of the developed digital application in the port of Antwerp including the different barge related applications.

Figure 3 Overview of the multilayer digital applications in the port of Antwerp (see online version for colours)

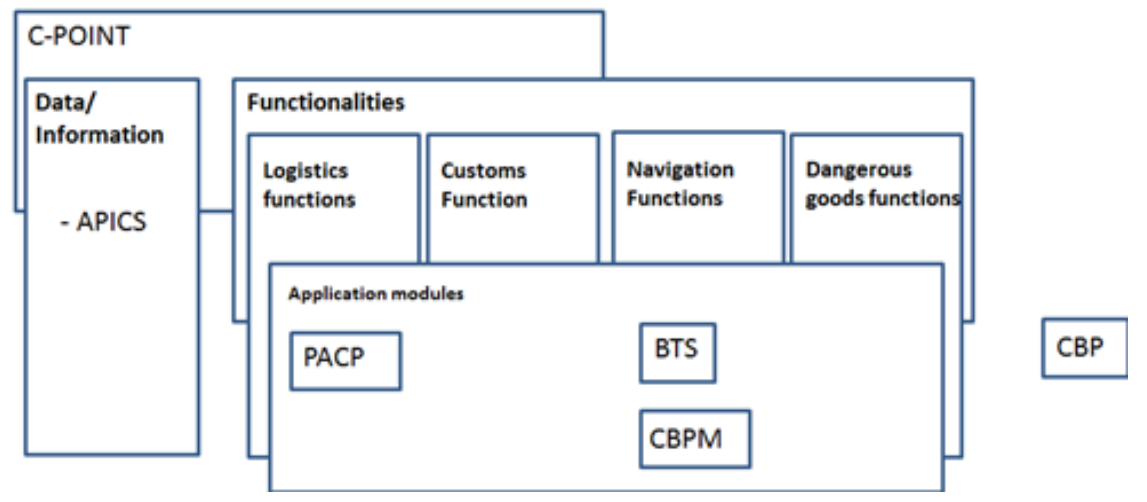

Source: Own elaboration based on Carlan et al. (2016)

The main platform, providing electronic data exchange at the port of Antwerp is the Antwerp Port Community System (APCS), renamed in 2018 to C-POINT. It provides electronic data exchange services at the port of Antwerp. C-POINT is a centralised informational exchange point connecting different stakeholders in and around port. This system hosts functionalities for nautical operations, customs transactions, hazardous goods declaration or cargo and logistics (Carlan et al., 2016; Port of Antwerp, 2016f).

Secondly, a functionality of C-POINT is the Antwerp Port Information and Control System (APICS). It is a port information system that plans, directs and monitors ship traffic. The monitoring is done from a vessel's movement perspective, navigating to, from and in the port of Antwerp. Equally, this system is used to control and manage barge and seagoing vessels in the port. Other supported functions of APICS, such as berth reservation, lock planning ${ }^{2}$, arrival/departure notification for vessels, cargo declaration, ordering of additional services (tug, pilotage, mooring, etc.) incorporate various operational systems and connect various external parties (Port of Antwerp, 2016b). C-POINT and APICS are major systems that give a basis to the development and further implementation of additional applications, aimed at harmonising and managing barge and deepsea vessel handling in the port of Antwerp. 
These main platforms need data to monitor, organise and plan barge and deepsea vessel operations. For coordination and management of barge traffic in the port of Antwerp, the automatic identification system (AIS) was implemented on barges and seagoing vessels. This system, based on GPS information transition (as per vessel name, position, speed and course), communicates with terminal operators and the traffic coordination centre. This way, it gives the possibility to the port operator to have a holistic view about traffic situation in port of Antwerp, to plan barge and deepsea vessel visits to locks, berths and terminals (Port of Antwerp, 2016d).

Besides the main, overarching applications, there are also dedicated barge transport systems. These are: the Barge Traffic System (BTS), the Central Barge Planning and Monitoring (CBPM) system, the Central Booking Platform (CBP) and the Premium Barge Service (PBS).

The first dedicated barge application is the BTS. This is a free web application, developed by the Antwerp Port Authority in collaboration with the barge container sector. This program introduced a system of slot booking for barges in real time and scheduling barge visits to the terminals at the port of Antwerp. The main aim of this application is the optimisation of barge flows within the port and idle time elimination. BTS represents one communication channel between barges carrying containers and terminal operators. This application is a continuous monitoring management system (including barge position, lock scheduling, details of terminal capacity and opening times, barge sailing schedule). Based on a barge operator's request, the terminal operator is forming a schedule of loading/unloading, processing information about free slots and terminal capacity and sending booking confirmation to the barge operator (Port of Antwerp, 2015). Since 2007, this tool has been updated to improve and stimulate the collaboration around container barge planning. In 2018, the tool has been updated and new functionalities have been added.

To avoid individual conflicts in requests, BTS exchanges information also with the CBPM system (second system). This system integrates different container terminal operators in the port of Antwerp to ensure better communication, eliminating the schedule overlapping of terminals and providing short turnaround for barges in port (Port of Antwerp, 2015).

Thirdly, the Port of Antwerp Connectivity Platform (PACP) offers an intermodal solution, providing shippers and port clients with online information about available transport options for their cargo. It consists of three tools: maritime connection, terminal connection and intermodal connection. Equally, this tool identifies the most appropriate type of transportation to the final destination (Port of Antwerp, 2016g)

The final application is the CBP, which is a new tool which focus on the coordination of cargo flows for logistics operators, developed upon initiative by the Antwerp Forwarders Association (VEA). The aim of this tool is cargo flow consolidation. The consolidation is done through bundling and combining two transport modes: rail and barge. This method generates benefits due to economies of scale, achieved through the consolidation of large transhipments, which offers a faster and simplified service. This application brings together forwarders and shippers by synchromodal planning, which enables parties to share all information about the container handling status (CBP, 2015). This approach makes collaboration between shippers easier and it increases the transparency between all actors in the port of Antwerp. Bundling, as it was mentioned in 
the previous section, enables actors not to act separately, but to increase efficiency performance and time scheduling of container handling (Port of Antwerp, 2016e; CBP, 2015). In the meantime, VEA passed on the CBP tool to a private operator, called LogitOne, who now further develops and runs the initiative.

Besides the digital application, there is also a non-digital application. This is the PBS, which has been brought into operation by Antwerp Port Shuttle and originates from the idea of bundling small container volumes. The objective is to reduce the number of terminal visits made by barges collecting/distributing containers. The PBS is a barge shuttle service, operating under fixed daily schedules with the purpose of consolidating small barge container volumes, and optimising resources and equipment usage (Port of Antwerp, 2015, 2016a).

Table 1 gives an overview of these applications. Also, the links between the different technologies and a number of criteria are given. These criteria are:

- Is it an open or closed development?

- To which port actors are there data sharing links?

- Will it improve the planning activity?

- Will it imply a time scheduling?

- Will it include multiple modes of transport?

- For whom is the technology developed?

- Which planning activities in the seaport are included?

- Will it involve bundling of cargo?

The pluses in Table 1 imply a positive relation between a chosen application and a certain feature or whether it provides that particular function. For instance, the BTS is an open application (everyone can use it) that serves only barge operations, but not trucks, rail or deepsea vessel services. Equally, BTS provides a slot booking functionality for container barges at quays (terminals) and depots, which is also marked with a plus. A minus implies that an application is not able to fulfil or link to a certain aspect and/or actor. If no information could be found, the cells are left empty.

From Table 1, it can be observed that all the applications involved are related to barge operations. With respect to the interaction between the barges and terminals, five of the seven investigated applications have a positive relation. This means that the slot booking service for a barge operator at a deepsea terminal is taken into account in these applications. Table 1 also shows that for all the developed applications, almost all relevant actors are targeted. This is in line with Meersman et al. (2010), in which port competition is viewed as competition between logistics chains, and in which ports are nodes. The same chain logic can also be applied in the port node itself. This means that container barge handling should be viewed as a part of a large chain. Incorporating all the different actors in a barge planning/optimisation tool implies that this chain approach is taken into account. 
Table 1 Overview of the different port-barge related applications

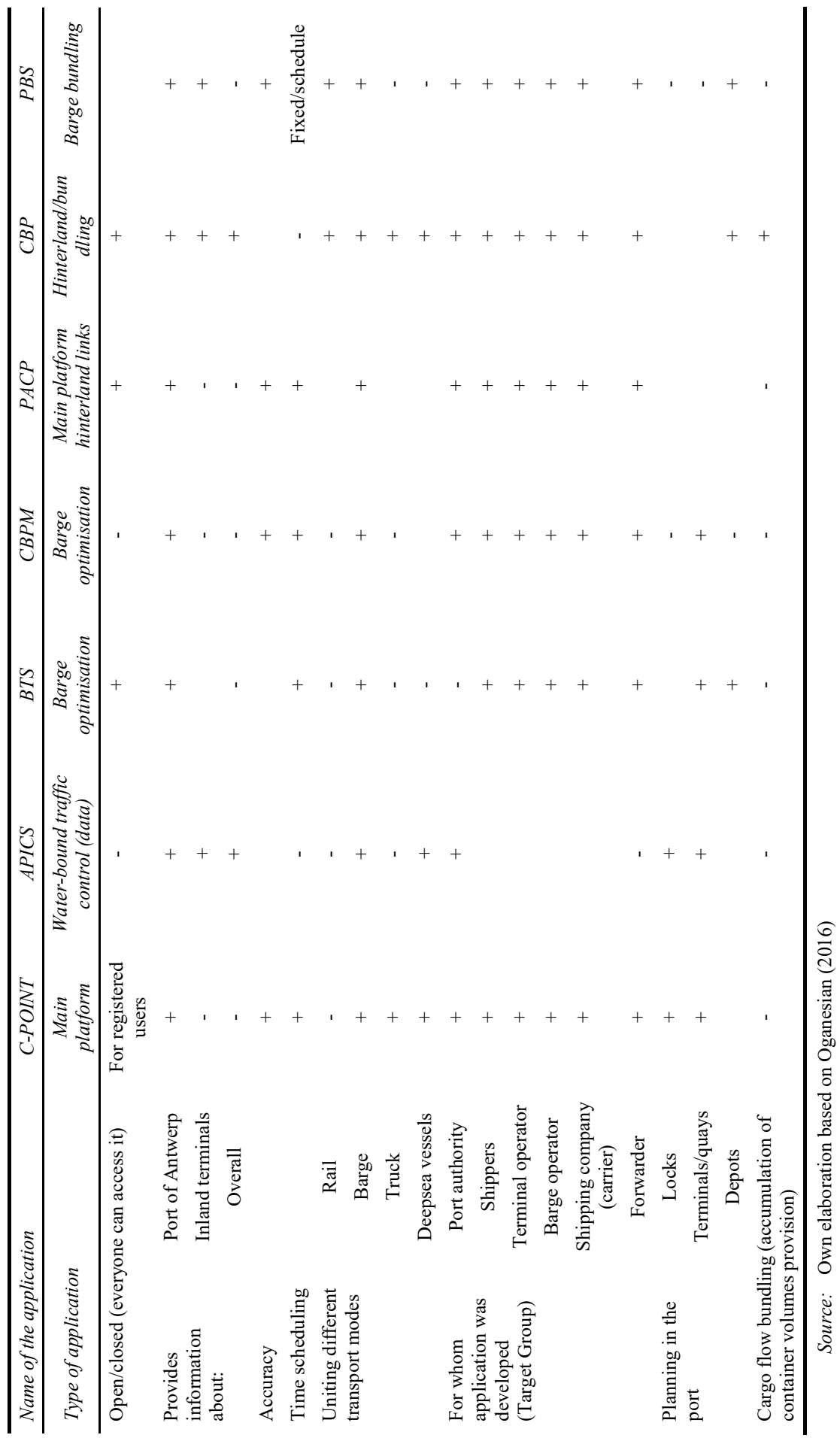


Table 2 Interaction between the developed applications

\begin{tabular}{lccccccc}
\hline Name of the application & C-POINT & APICS & BTS & CBPM & $C B P$ & PACP \\
\hline Integration & C-POINT & $/$ & + & + & + & - & + \\
with other & APICS & & $/$ & & & & \\
applications & BTS & & & $/$ & + & & - \\
& CBPM & & & $/$ & & - \\
& CBP & & & & $/$ & - \\
& PACP & & & & & & \\
\hline
\end{tabular}

Source: Own elaboration based on Oganesian (2016)

Table 2 displays the ability of the different applications to be linked to the other applications. The interpretation of the different symbols in Table 2 is the same as in Table 1.

Table 2 shows that the C-POINT has the ability to communicate and interact with most of the other applications. Only the CBP is excluded. This application works on a stand-alone basis. The PBS is excluded from this table because it is not a digital application.

Furthermore, since November 2018, the Port of Antwerp has a pilot project running in which inland container barges are only allowed to call at the main container terminals in the seaport with at least 30 containers to be handled. Barges with less than this minimum call size are obliged to first consolidate up to at least 30 barges, either a consolidation hub inside the port, or at an inland terminal outside the port. The rationale behind this is that bundling small volumes to larger call sizes ensures a less complex planning process and a more efficient use of the resources by terminal and barge operators. This approach however increases the handling cost due to an extra handling at the consolidation hub. During the pilot project, this cost is limited to $€ 5$ per move for containers bundled at a hinterland container terminal and to $€ 10$ per move at a terminal in the port area. These prices do not cover the total handling cost. Hekkenberg (2012) applied in his model an average cost varying between 25 EUR and 30 EUR per move. Starting from this assumption, hence, the difference between the actual handling cost and the price set is covered by the port of Antwerp authority (i.e., subsidised). The pilot project would operate on a reduced subsidy basis, where the need to subsidise barge operators with low parcel volumes would be gradually eradicated. (Port of Antwerp, 2018).

Based on the performed literature study, it can be concluded that the delays are caused by a lack of coordination between the deepsea terminals and the barge operators, which is caused by the small call size of container barges at deepsea terminals and a lack of having a contractual relation between both the deepsea terminal and the barge operator. This has led to the situation that container barge handling in a seaport is a chaotic process, which leads to large delays and high unreliability. In order to overcome these issues in the port of Antwerp, several solutions have been developed, such As the co-creation of NxtPort, a Data Utility Platform, empowering the port community system C-Point and applications like BTS. This paper will analyse to what extent the impact of the identified problems can actually be quantified, and what variables the provided solutions should work on so as to improve the attractiveness of inland navigation. 
In order to determine the effect of the unreliability of container barge transport, a case study will be performed. The case study reflects a real case of a company, which uses barge transport to transport containers from the port of Antwerp to their premises at an inland terminal $30 \mathrm{kms}$ south of the port. This case study is presented in the next section.

\section{Case study (Umicore)}

A case-based approach is used for the empirical part. Such approach is helpful to get insight in into the impact of barge unreliability on a shipper. The developed case study consists of four main sections. Firstly, the case study setting is determined. Secondly, the evaluation method is presented, followed by the used data. Finally, the results of the case study are explained.

\subsection{Case study setting}

The case involves Umicore, a global materials technology and recycling group located in the close proximity of the port of Antwerp and their logistics service provider Van Moer Logistics. Umicore uses barge transport, managed by Van Moer Logistics, to transport containers from the port of Antwerp to Hoboken (Belgium), hence on-site logistics (Figure 4).

Figure 4 Case study setting (see online version for colours)

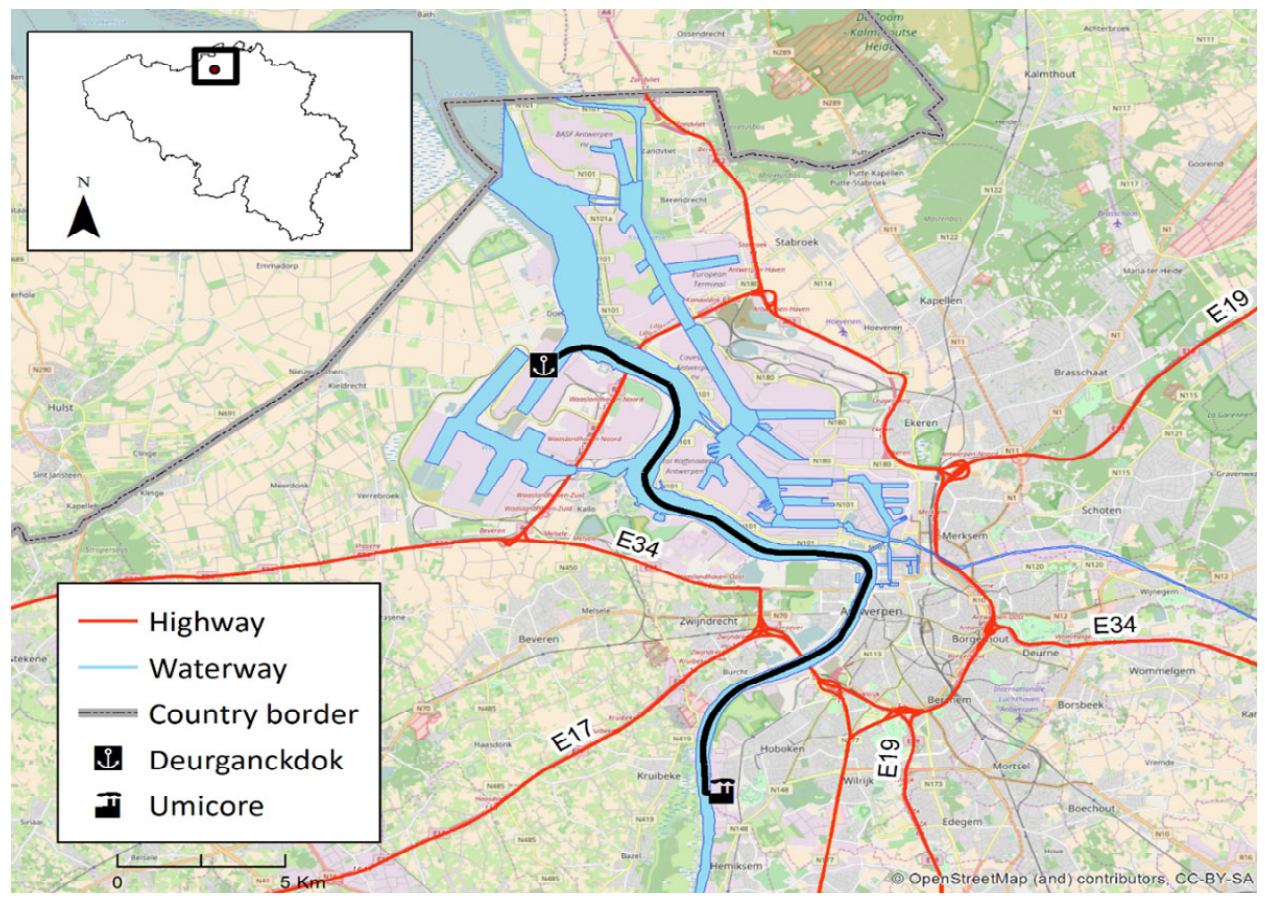

Source: Own compilation 
Figure 4 shows that the distance from the seaport to the inland terminal in Hoboken is rather short $(30 \mathrm{~km})$. Moreover, there are no locks on the sailed trajectory. So, this means that the large variance in lead time could almost directly be allocated to the handling of the barges in the port area and not to effects on the sailed trajectory.

\subsection{Evaluation method}

In order to quantify the (un)reliability of barge transport, a methodological framework is needed. The unreliability of barge transport can be estimated by measuring the variance of lead time. If the variance is low, the reliability of the transport is high, while if the variance is high, the reliability of transport is low.

The effect of the variance of the lead time is best reflected if the total logistics costs of transport are calculated. Not only the direct transport-related costs but also the inventory costs are taken into consideration in the total logistics costs. Baumol and Vinod (1970) argue that faster and more reliable transport modes, while yielding higher transportation costs, reduce the shipper's inventory costs. This methodology has also been applied in Blauwens et al. (2006), where also an application is made with respect to barge transport.

For the proposed case study, a supply chain with a single supplier and receiver (e.g., from the port of Antwerp to the dedicated inland terminal in Hoboken), which corresponds to the first typology (domestic trade), is studied. In order to deliver the goods from the port to the receiver, in this research, only inland navigation is used. The transport via inland barges is characterised by four so-called 'logistics characteristics': transportation costs, shipment size, average lead time and variance of lead time. The goods flow itself is characterised by six parameters: annual volume, average daily demand, variance in daily demand, value of the goods, holding cost and the service level required by the receiver (Blauwens et al., 2006).

The total logistics cost can be calculated by equation (1) (Blauwens et al., 2006):

$$
T L C=T C+\left(\frac{1}{R} \cdot \frac{Q}{2} \cdot v \cdot h\right)+\left(L \cdot v \cdot \frac{h}{365}\right)+\left(\frac{1}{R} \cdot v \cdot h \cdot K \sqrt{L \cdot d+l \cdot D^{2}}\right)
$$

In which

$T L C$ the total logistics costs (EUR/TEU)

$T C$ the out-of-pocket costs for the transport (EUR/TEU)

$R \quad$ the annual volume (TEU/year)

$Q \quad$ the shipment size (TEU)

$v \quad$ the value of cargo (EUR/TEU)

$h \quad$ the holding cost (\%/year)

$L \quad$ the average lead time (days)

$K \quad$ a safety factor related to the risk of zero stock

$d \quad$ the variance of daily demand $\left(\mathrm{TEU}^{2} /\right.$ day)

$l \quad$ the variance of the lead time $\left(\right.$ days $\left.^{2}\right)$ 
$D \quad$ the average daily demand (TEU/day).

The TLC consists of four terms. First, the TC includes all monetary costs, such as the transport cost and the handling cost. The second term refers to the costs of cycle stock. The third term represents the costs of inventory in transit. The final term refers to the costs of safety stock.

As can be observed from equation (1), the lead time and the variance of the lead time both affect the in-transit-inventory and the safety stock.

The $T C$ is determined as the sum of the transport price plus the handling charges at the inland terminal. This cost is estimated based on the data taken from an inland terminal operator.

The variable $R$ can be derived from the data that is obtained from the selected case study. In the dataset, the actual dates when the containers arrive at the port of Antwerp are registered. This data is used to determine the average daily demand, but also the variation of the daily demand. Based on the same dataset, the total demand can be derived. Starting from the difference between the actual departure time of containers in the port of Antwerp and the actual arrival time at the inland terminal, both the average lead time and the variance of the lead time can be calculated. The holding cost, the value of cargo and the risk of stock-out cost depend on company-specific parameters.

\subsection{Data used in the case study}

Company-specific data is used for the analysis. Umicore is facing long lead times for their containers delivered from deepsea terminals, located at port of Antwerp, to their dedicated inland terminal at Hoboken. Umicore provided a large data file containing the following information at container level ${ }^{3}$ :

- container imports (quantity) for the period of the end of November 2014 to October 2015

- date of container arrival at the deepsea terminal (port of Antwerp)

- actual date of arrival of container at the inland terminal at Hoboken

- date of delivery of empty container from the plant to the terminal in Hoboken (after stripping, cleaning, etc.)

- actual date of picking up empty container by barge at the terminal in Hoboken

- $\quad$ actual date of empty container delivery to an empty depot in the port of Antwerp.

All the data is expressed in calendar days. This means that the unit of measurement is the number of days. The data has been selected and grouped in accordance to three processes (Figure 5):

1 container delivery from deepsea terminal to inland terminal in Hoboken

2 period between empty container`s delivery to the terminal in Hoboken and picking it up by barge

3 empty container delivery from inland terminal at Hoboken to port of Antwerp.

For all three aforementioned segments, the corresponding time intervals can be determined. Thus, for each of the total number of containers, which is equal to 
4,477 TEU per annum, the delivery time was calculated. The average lead time (Antwerp-Hoboken) amounted to $6.88 \approx 7$ days.

Figure 5 Overview of the different flows and lead time data (see online version for colours)

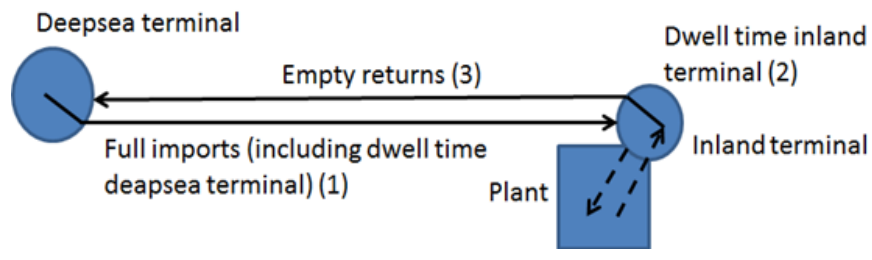

Figure 6 shows the wide variance in lead time for the import flows. The most frequent time interval, which is 6 days (frequency of occurrence is 967) constituting only $21.6 \%$ from the entire scope. Figure 6 depicts that $75 \%$ of the total deliveries lay at the interval between 2 and 8 days. The remaining 25\%, which are 697 container deliveries, lay in an extreme range from 9 up to 30 days. Table 3 gives the summarising statistics of the import flows.

Table 3 Summarising statistics of the import flows

\begin{tabular}{lccc}
\hline Summary statistics & \multicolumn{2}{c}{ Tested mean } \\
\hline Mean & 6.880 & & \\
Median & 6 & Test statistic & 0.0089 \\
Std. dev. & 3.752 & Prob $>$ abs $(\mathrm{Z})$ & 0.9929 \\
Std. err. mean & 0.056 & Prob $>\mathrm{z}$ & 0.4964 \\
N & 4,477 & Prob $<\mathrm{z}$ & 0.5036 \\
\hline
\end{tabular}

Figure 6 Frequency table of the lead time for containers` delivery from Antwerp to Hoboken within the sample period (see online version for colours)

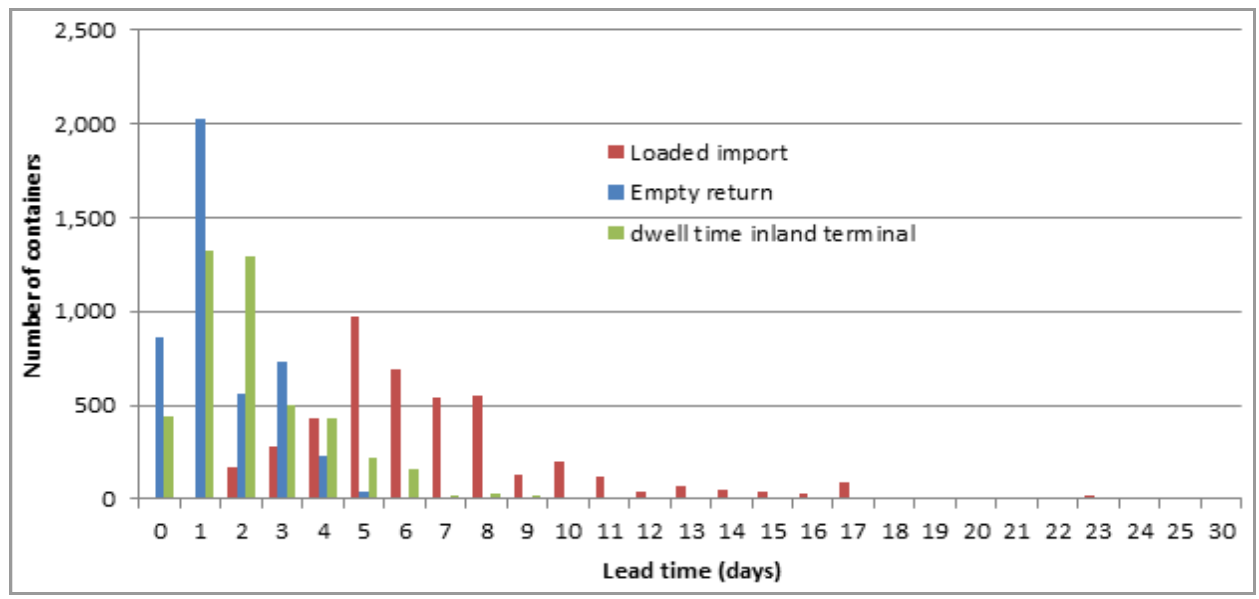

Source: Own compilation, based on Umicore Data (2016) 
From the same dataset, the dwell time of a container at the inland terminal in Hoboken can also be determined. The average dwell time was 2.3 days, while the maximum transport time is one day, which constitutes $58.5 \%$ of the total sample. Some occasional periods of picking up empty containers within long duration (from 7 to 22 days) amount to $2.4 \%$ of the sample, which is quite negligible.

The lead time to transport a container from the inland terminal to the port of Antwerp is on average 1.5 days, with a standard deviation of 1.408 days. The distribution of values is rather narrow. The main distribution of values is between 0 and 3 days (near $94 \%$ of the total); only $6 \%$ of the values are between 4 to 25 days. These quick deliveries only show the proximity of inland terminal location to the port and do not reflect empty container handling time at the port of Antwerp itself.

Figure 6 shows the big difference between the import and the export container flows. The variance for full containers is quite large (14 days), which could be explained by a multitude of factors, such as transaction and storage time, resulting from controlling agencies' performance, and, more importantly, the strategies of importers and customs brokers. An importer often has a strong incentive to use ports as storage areas. At the port of Antwerp, the free storage time is around six days, depending on the liner operator (CMA-CGM, 7; Maersk, 7; MSC; 4; Hamburg-Sud; 5; and COSCO, 5). This means that for the import flows, the importer can opt to leave the container in the port and take advantage of the free storage space. This could be the reason why the average lead time is as large as the free storage time. However, $57.1 \%$ of all the observed lead times are lower than six days. Moreover, interviews with the port authority, Umicore, barge operators and terminals, as well as sector literature ${ }^{4}$ show that the variance in the Umicore case is more related to the barge congestion problems in the port and low priority of barges at deepsea terminals. If the empty containers are analysed, the variance is two days, which shows that dropping off empty containers via empty depots causes much less variance in the lead time. Also the average lead time for drop offs is much smaller. This is related to the fact that the container needs to be returned to the empty depot. Most containers (64\%) are dropped at an empty depot within less than one day. This is a clear reflection of the short sailing distance $(<30 \mathrm{~km})$ and the lack of interference of deepsea vessels at the empty depots in the port.

To determine and to evaluate the demand of barge transportation, it was necessary to look at the demand for container transport in the sample period. The container demand is determined by the actual number of container arriving, per day, at the inland terminal. All of these containers have an origin in the port of Antwerp. Figure 7 shows this actual container arrival distribution per day over a year.

This actual arrival distribution of the containers at Hoboken is used as the actual demand for transport. Based on this data, it is possible to derive the daily demand for transport as well as the variance in this daily demand. This can be done by calculating the average number of containers arriving per day along with the variance. The reason to calculate this, is to ensure that the units of transport demand and variance in transport demand are equal to that of the lead time and the variance of lead time so that the safety stock levels and cost can be calculated [see equation (1)]. 
Figure 7 The actual container demand (see online version for colours)

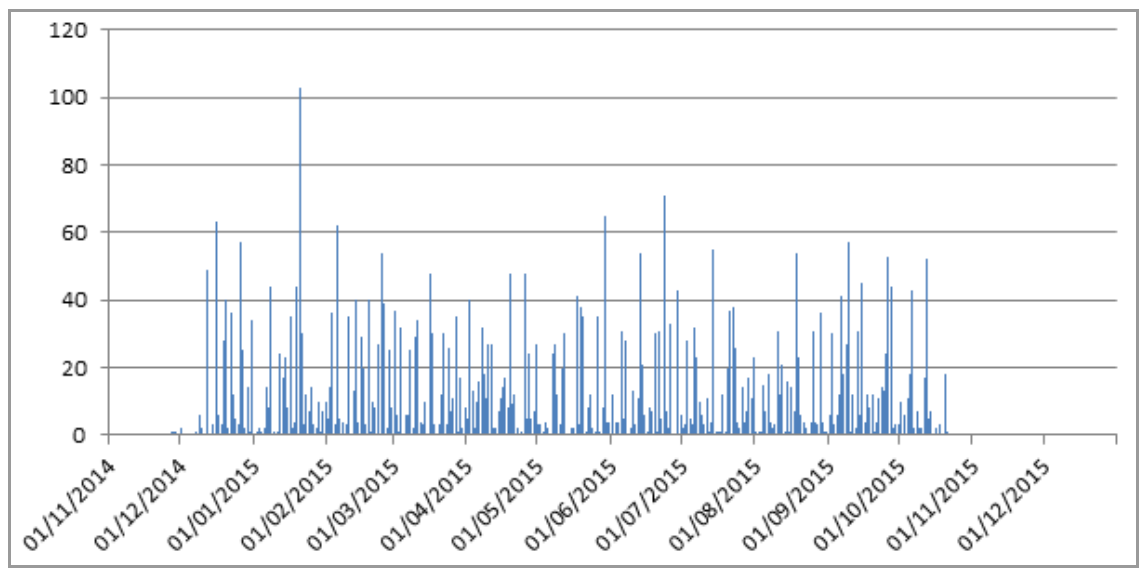

Source: Own compilation, based on Umicore Data (2016)

From Figure 7, it can be observed that there is a large variation in the daily container demand. Table 4 provides the summarising statistics. The average demand for container transport is 14 containers per day, with a standard deviation of 16 containers.

Table 4 Determination of mean and standard deviation of the daily demand for import containers

\begin{tabular}{lccc}
\hline Summary statistics & \multicolumn{3}{c}{ Tested mean } \\
\hline Mean & 13.602 & Test statistic & 0.0009 \\
Median & 6 & Prob $>$ abs $(\mathrm{Z})$ & 0.9993 \\
Std. dev. & 16.144 & Prob $>\mathrm{z}$ & 0.4996 \\
Std. err. mean & 0.89 & Prob $<\mathrm{z}$ & 0.5004 \\
N & 329 &
\end{tabular}

The transport cost is based on the actual price for transporting a TEU from the port of Antwerp to Meerhout inland terminal. For the trip from Antwerp to Meerhout, the total transport price is $€ 107 / \mathrm{TEU}$ (BCTN, 2015). In order to estimate the transport price between Antwerp and Hoboken, the sailing distance ratio is used to scale the transport price. The total transport distance between Antwerp and Meerhout is $77 \mathrm{~km}$, while the sailing distance from Antwerp to Hoboken is $26 \mathrm{~km}$. The handling cost per TEU at an inland terminal is estimated at $€ 29 / \mathrm{TEU}^{5}$ (Hekkenberg, 2012). If the handling costs are subtracted from the transport price, the distance-related transport price can be obtained. If the sailing distance ratio is applied and the handling charge is added, the total transport price Antwerp-Hoboken can be estimated at $€ 55 / \mathrm{TEU}$.

For the calculations, the allowance of a stock-out is set at $1 \%$. This results in a factor $K$ of $2.33^{6}$. The value of the cargo is difficult to determine, but Hurkmans (2018) provides an overview of the value of the cargo inside a container, which is being shipped via the port of Antwerp. The average value is approximately $€ 60.000 / \mathrm{TEU}$. 
Based on the analysed and the collected data for transport cost and cargo parameters, the following base case input parameters are obtained (Table 5).

With the data from Table 5, in Section 5, the TLC can be determined and a sensitivity analysis can be made to determine the effect of changing the variation of the lead time on the total logistics cost.

Table 5 Main input parameter for the TLC calculation

\begin{tabular}{lccccc}
\hline $\begin{array}{l}\text { IWT } \\
\text { parameters }\end{array}$ & \multicolumn{5}{c}{$\begin{array}{c}\text { Cargo } \\
\text { parameters }\end{array}$} \\
\hline $\mathrm{TC}$ & {$[\mathrm{EUR} / \mathrm{TEU}]$} & 55 & $\mathrm{R}$ & {$[\mathrm{TEU}]$} & 4,475 \\
$\mathrm{Q}$ & {$[\mathrm{TEU}]$} & 13.114 & $\mathrm{~K}$ & {$[-]$} & 2.33 \\
$\mathrm{~L}$ & {$[$ Days] } & 6.881 & $\mathrm{D}$ & $\mathrm{TEU} / \mathrm{day}]$ & 12.602 \\
1 & {$\left[\right.$ days $\left.^{\wedge} 2\right]$} & 14.077 & $\mathrm{~d}$ & {$[$ TEU^2/days $]$} & 13.114 \\
& & & $\mathrm{v}$ & {$[$ EUR/TEU] } & 60,000 \\
& & & $\mathrm{~h}$ & {$[\% /$ year $]$} & $5 \%$ \\
\hline
\end{tabular}

\subsection{Results}

Based on the input parameters summarised in Table 5, the TLC can be calculated. Figure 8 gives the results of the calculations. In the base case (based on the input parameters of Table 5), the TLC is equal to $€ 196.10 / \mathrm{TEU}$. Of this cost, $67 \%$ is determined by the safety stock (39\%) and the in-transit inventory cost $(29 \%)$. These cost factors are related to the lead time and the variance of the lead time, which are both related to the delays and (un)reliability of barge operations in a seaport. This shows that reliability and lead time are very important factors, and that an improvement of these could lead to substantial cost savings for the shipper, especially for shipments on very short distances from the port.

Figure 8 Impact of variation of lead time and variance of lead time (see online version for colours)

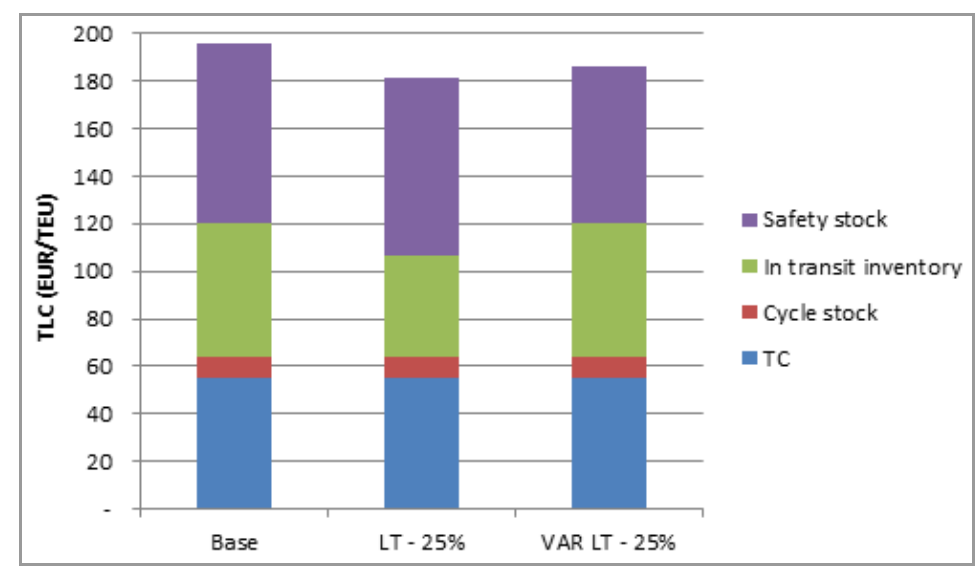


The effect on the TLC of reducing the lead time by $25 \%$, all the other cost elements kept constant, is a decrease by $7.55 \%$. If the variance of the lead time is decreased by $25 \%$, all the other factors kept constant, the TLC decreases by $5.13 \%$.

Figure 9 Sensitivity analysis of varying lead time and variance of the lead time (see online version for colours)

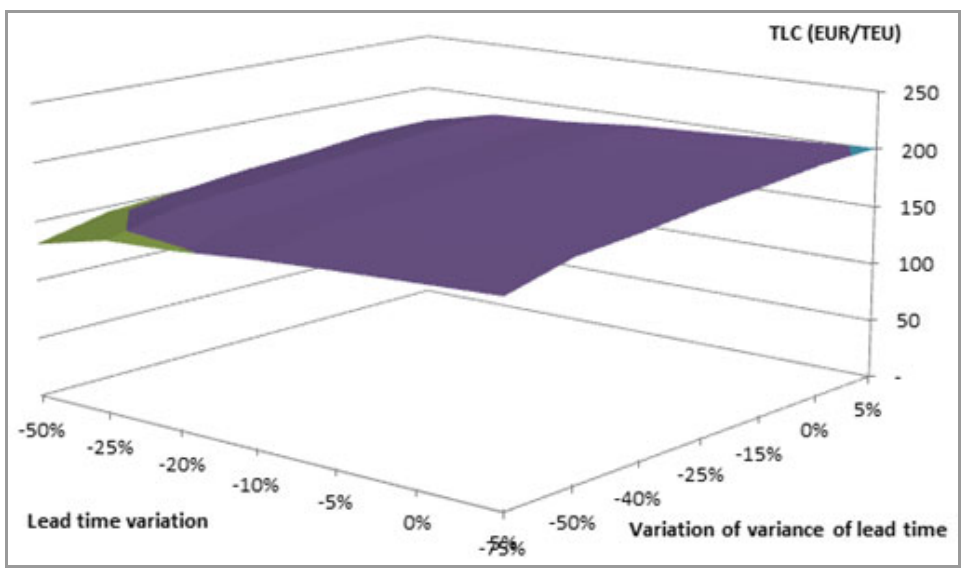

Numerous combinations are possible with a reduced lead time and variance of the lead time. In Figure 9, the impact is shown of changing the lead time from $+5 \%$ to $-50 \%$, relative to the base situation, and similar for the variance of the lead time $(+5 \%$ to $-75 \%)$.

A reduction of the variance by $75 \%$ implies a reduction of the standard deviation by $50 \%$. Given the large standard deviation (3.75 days), a reduction to half of this value could be possible.

The TLC varies from $€ 200.94 / T E U$ in the case that both the variance of and the lead time itself will increase by $5 \%$, to $€ 130.95 / \mathrm{TEU}$ when the variance of the lead time decreases by $75 \%$ and the lead time by $50 \%$. Given that in the sample, a total of 4.475 TEUs are shipped, a total cost reduction of $€ 291,535$ for the company could be achieved if the standard deviation of the lead time (variance $-75 \%$ ) could be reduced by $50 \%$ and the lead time itself also.

Figure 10 Impact of a reduction in variance of lead-time on the TLC savings (reversed X-axis) (see online version for colours)

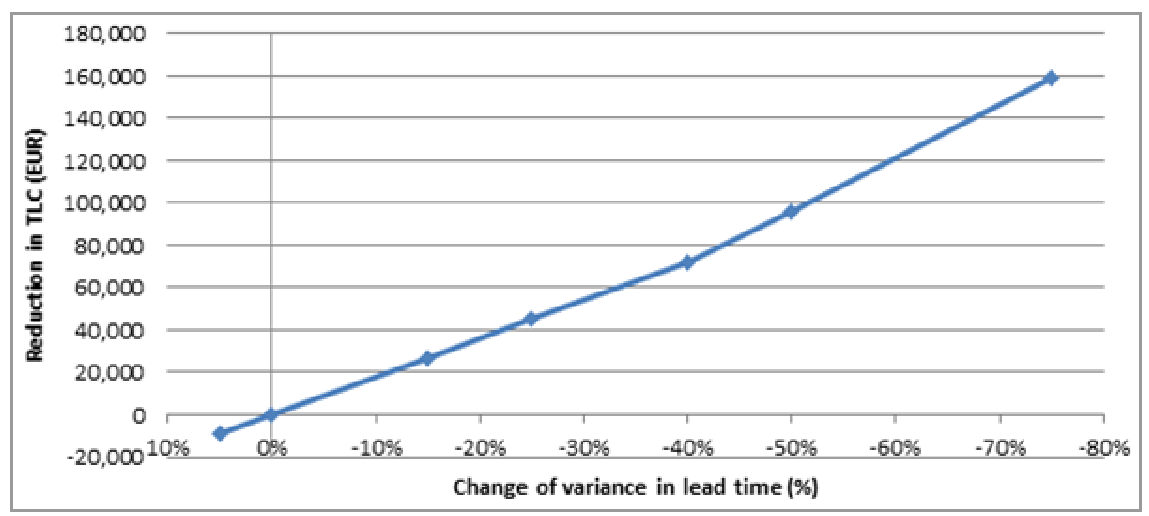


If only the reduction in the variance of the lead time (the main indicator of barge handling unreliability) is taken into account, the TLC savings can be found in Figure 10.

If the variance is reduced by $75 \%$, which is equal to decreasing the standard deviation from 3.75 days to 1.9 days, the total TLC savings are at $€ 160,000$ for a period of 11 months $(4,450$ TEUs). A reduction by $50 \%$ in variance, which is a reduction by $30 \%$ in standard deviation of the lead time, will lead to a TLC savings of nearly $€ 100,000$.

In the calculations, the value of the cargo is set at $€ 60,000$ per TEU. This value is an average of container imports for Europe. If the cargo inside the container would have another value, the results of the calculations would also differ. In Figure 11, the results of varying the value of the containerised cargo on the TLC savings are shown for the situations in which the variance is reduced by $75 \%$ and the lead time by $0 \%$ and $50 \%$ respectively.

Figure 11 Impact of the value of cargo on the total savings in TLC (see online version for colours)

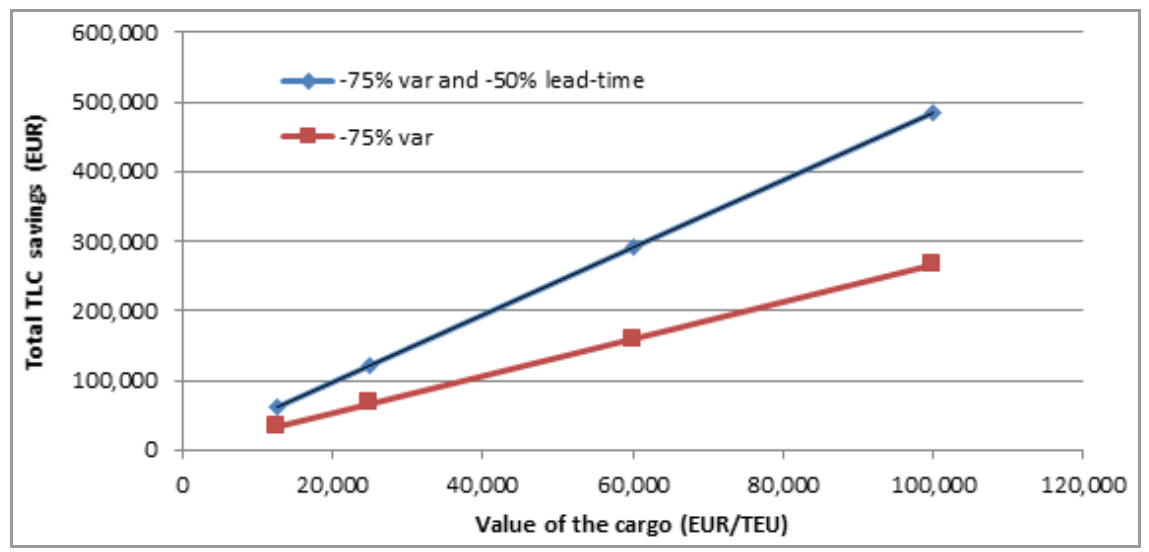

Figure 11 shows that the total TLC savings, if the lead time and the variance are reduced, are in the range from $€ 60.000$ for low-value cargo ( $€ 12,500 / \mathrm{TEU})$ to $€ 500,000$ for very high-value cargo ( $€ 100,000 / \mathrm{TEU})$. If only the reduction in variance is taken into account, the impact of a changing value of the cargo inside the container is less than when also the reduction in the lead time is taken in account. If only the reduction in the variance is further analysed, then it can be observed that the total savings in TLC are in the range between $€ 33,000$ for low-value containers and $€ 265,000$ for high-value containers, purely due to a reduction in safety stock.

\section{Conclusions}

This paper considers the impact of barge handling unreliability in a large sea port, with a focus on the port of Antwerp. Next to that, also a case study analysis is made for a company, which is affected by this barge unreliability. The added value of this case study is that company-specific data is used.

The research shows that container barge unreliability is a major element, which contributes negatively to the overall barge transport performance, especially on short distances. The main reason for this unreliability is the low priority that barge operators 
get at deepsea terminals. This is caused by the fact that barge operators do not have a contractual agreement with the deepsea terminal operators. Barges also make several calls at the different container terminals in the ports, which makes that barges accumulate congestion and decrease their reliability even further.

In order to solve these issues, several solutions were proposed. From the literature review, it can be concluded that the open dialogue between all actors (skipper, terminal operator, shipping company, associations and interest groups, barge operators) on a regular basis could improve efficient handling of barges. Moreover, several initiatives have been taken to improve the barge handling in the port of Antwerp. All of these applications involve technologies to improve the real-time knowledge of the positions and final destinations of container barges in the port. Also links are made between the barge operator and the different port actors. This makes that container barges can be planned better in the seaport. Especially information and communication technology can bring objectivity and rationality to solving coordination problems, so it is typically used to solve the lack of operational coordination and, to a smaller extent, to improve the utilisation of assets. The combination of all these ICT initiatives ensures an optimisation of inland container shipping, an efficiency increase for all actors in the chain and more attractiveness of the port of Antwerp.

The implication for shippers is that due to an improvement in barge handling reliability, the safety stock levels of the receiving companies can be reduced. This implies a cost reduction, which increases with increasing value of the cargo shipped in a container. The improvements of the barge handling reliability are most notable for shipments of containers to inland terminals which are relatively close to the port. This is due to the fact that the TLC is mostly determined by other cost components than the pure transport price. If the same level of barge unreliability is observed for shipments to inland ports located further away, say in Germany, the effect of barge unreliability becomes less. This means that if a modal shift towards barge transport is aimed for, then, especially for local short distance transport, an improvement in barge handling reliability would reduce the TLC and, as a result, would stimulate the use of inland navigation.

From the calculations of the case study, it can be concluded that the cost savings for the company could be very substantial. This cost saving is obtained by a reduction in lead time and a reduction in the variance of the lead time. If only the reduction in variance is taken into account (improvement of reliability), then still 55\% of the initial cost savings can be obtained. This shows that the benefits for the shipper can be very substantial if the reliability is improved and that investments in port applications to improve the barge handling reliability are needed.

Limitations of the research are that the observed data are measured in days. As a result, the transport time and the variances in transport time can only be determined on a day basis. Data on an hourly basis would have increased the accuracy of the calculations. The research of the developed port-related applications and the case study is limited to Antwerp. From the more general literature review, it was found that the problems of barge handling are similar in most of the biggest container ports in Europe, which all have a high share of inland navigation for their hinterland transport. Therefore, the results of this case study can also be useful for basically any other major port which deals with container barge hinterland transport.

Particularly interesting for further research would be the same analysis of lead time in the evaluation of all new measures (container hub, digitalisation, ...) within the Antwerp Action Plan 'Container Barge'. Congestion did not disappear completely, but got strongly 
reduced. Hence, studying the impact on barge congestion of opting for a mix of measures would be a useful area for further work.

From an operational point of view, imposing a minimum call size is nevertheless more complex and entails additional costs. A cost/benefit analysis of this concept could be usefully explored in further research. Further work needs to be done with respect to the risk of reverse modal shift (due to increased complexity, shippers opt for road transport). The research results are relevant for all actors involved in barge hinterland transport. In that sense, the analysis conceptually is also applicable to other ports that feature similar inland navigation use as well as congestion problems.

From a scholarly point of view, this paper contributed in a novel way to the conceptual analysis of impacts of lead time and variance in lead time, by developing an expansion to the general cost formula by Blauwens et al. (2006), tailored to a concrete inland navigation case.

\section{Acknowledgements}

The authors want to thank the editor and two anonymous referees for the valuable comments and suggestions to improve the quality of this paper. Also the input and feedback from the belated Dennie Lockefeer, Van Moer Logistics and Elsje Verdoodt, Umicore are highly appreciated.

\section{References}

Baumol, W.J. and Vinod, H.D. (1970) 'An inventory theoretic model of freight transport demand', Management Science, Vol. 16, No. 7, pp.413-421.

BCTN (2015) Personal Information Obtained from BCTN.

Blauwens, G., De Baere, P. and Van de Voorde, E. (2016) Transport Economics, 6th ed., Uitgeverij De Boeck nv, Antwerp.

Blauwens, G., Vandale N., van de Voorde E., Vernimmen, B. and Witlox, F. (2006) 'Towards a modal shift in freight transport? A business logistics analyses of some policy measures', Transport Reviews, Vol. 26, No. 2, pp.239-251.

Caris, A., Macharis, C. and Janssens, G.K. (2011) 'Network analysis of container barge transport in the port of Antwerp by means of simulation', Journal of Transport Geography, Vol. 19, No. 1, pp.125-133.

Carlan, V., Sys, C. and Vanelslander, T. (2016) 'How port community systems can contribute to port competitiveness: developing a cost-benefit framework', Research in Transportation Business \& Management, pp.1-14, ISSN: 2210-5395.

Central Booking Platform (CBP) (2015) Best Fact, Best Practice, Case Quick Info [online] http://www.bestfact.net/ (accessed 10 May 2016).

Fattahi, M., Govindari, K. and Keyvanshokooh, E. (2016) 'Responsive and resilient supply chain network design under operational and disruption risks with delivery lead time sensitive customers', Transportation Research Part E: Logistics and Transportation Review, Vol. 101, pp.176-200.

Frémont, A., Franc, P. and Slack, B. (2009) 'Inland barge services and container transport: the case of the ports of Le Havre and Marseille in the European context', Cybergeo: European Journal of Geography, Espace, Societe, Territoire, Document 437 [online] http://www.cybergeo.eu/ index $21743 . \mathrm{html}$. 
Hekkenberg, R. (2012) Inland Ships for Efficient Transport Chains, PhD thesis, Technische Universiteit Delft.

Hurkmans, A. (2018) Cargo Value Data from the Port of Antwerp.

Konings, J.W. (2009) Intermodal Barge Transport: Network Design, Nodes and Competitiveness, Delft University of Technology, TU Delft.

Konings, R. (2007) 'Opportunities to improve container barge handling in the port of Rotterdam from a transport network perspective', Journal of Transport Geography, Vol. 15, No. 6, pp.443-454.

Kotowska, I., Mańkowska, M. and Pluciński, M. (2018) 'Inland shipping to serve the hinterland: the challenge for seaport authorities', Sustainability, MDPI, Open Access Journal, Vol. 10, No. 10, pp.1-17, September.

Malchow, U. (2014) 'Port feeder barge: advanced waterborne container logistics for ports', TransNav., Vol. 8, No. 3, DOI: 10.12716/1001.08.03.12.

Marufuzzaman, M. and Ekşioğlu, S. (2016) 'Managing congestion in supply chains via dynamic freight routing: an application in the biomass supply chain', Transportation Research Part E: Logistics and Transportation Review, Vol. 99, pp.54-76.

Meersman, H., Van de Voorde, E. and Vanelslander, T. (2010) 'Port competition revisited', Review of Business and Economics, Vol. 55, No. 2, pp.210-232, ISSN: 2031-1761.

Meeussen, C. (2016) Parkeerapp voor binnenvaart wint eerste havenhackaton [online] http://www.flows.be/nl/shipping/parkeerapp-voor-binnenvaart-wint-eerste-havenhackaton.

Notteboom, T. (2007) 'Inland waterway transport of containerised cargo: from infancy to a fully fledged transport mode', Journal of Maritime Research, Vol. 4, No. 2, pp.63-80.

Oganesian, V. (2016) The Impact of Container Barging (Un)reliability in Seaports on Shippers: The Case of the Port of Antwerp, Master thesis C-MAT.

Port of Antwerp (2015) Instream. Smart and Efficient Inland Navigation [online] http://www.portofantwerp.com/en/instream/nautical-coordination (accessed 5 May 2016).

Port of Antwerp (2016a) Premium Barge Service [online] http://www.portofantwerp.com/en/ effective-distribution-within-port\#PBS (accessed 17 May 2016).

Port of Antwerp (2016b) APICS, The Antwerp Port Information and Control System [online] http://www.portofantwerp.com/apcs/en/apics (accessed 17 May 2016).

Port of Antwerp (2016c) Intermodal Solutions \& Connectivity Platform [online] http://www. portofantwerp.com/en/intermodal-solutions-connectivity-platform\#intermodal (accessed 17 May 2016).

Port of Antwerp (2016d) Nautical Coordination [online] http://www.portofantwerp.com/en/ nautical-coordination (accessed 17 May 2016).

Port of Antwerp (2016e) Central Booking Platform [online] http://www.portofantwerp.com/en/ news/central-booking-platform-intermodal-solution (accessed 17 May 2016).

Port of Antwerp (2016f) The Antwerp Port Community System [online] http://www.portofantwerp. com/apcs/en/about (accessed 17 May 2016).

Port of Antwerp (2016g) The Port of Antwerp Connectivity Platform [online] http://www. portofantwerp.com/nl/intermodal-solutions-connectivity-platform\#connectivity (accessed 17 May 2016).

Port of Antwerp (2018) Optimising of Container Barge Handling [online] https://www. portofantwerp.com/en/optimising-container-barge (accessed 17 May 2016).

Port of Antwerp (2019) IWT Containerised Cargo Volume (1998-2018) at the Port of Antwerp.

Samuel, L. (2019) Modeling of the Cost and Benefits of Creating Additional Barge Handling Capacity at the Port of Antwerp (Deurganckdok), Master thesis, Universtity of Antwerpen.

Schut, M., Kentrop, M., Leenaarts, M., Melis, M. and Miller, I. (2004) 'Approach: decentralised rotation planning for container barges', in ECAI, August, Vol. 16, p.755. 
Shobayo, P. and van Hassel, E. (2019) 'Container barge congestion and handling in large seaports: a theoretical agent-based modeling approach', Journal of Shipping and Trade, Vol. 4, No. 4, pp.1-26, ISSN: 2364-4575.

Slack, B. (1999) 'Satellite terminals: a local solution to hub congestion?', Journal of Transport Geography, Vol. 7, No. 4, pp.241-246.

Umicore Data (2016) Lead Time Data for Container Transport Antwerp, Hoboken

Van der Horst, M. (2016) Coordination in Hinterland Chains, An Institutional Analysis of Port-Related Transport, PhD thesis TU Delft, TRAIL Thesis Series No. T2016/19, The Netherlands Research School TRAIL.

Vercauteren, D. (2015) 'Inland waterway transport \& inland navigation in the Port of Antwerp', Materials of Presentation from APEC - Antwerp Seminar 'Inland Waterways Transport'.

Visser, J., Konings, R., Pielage, B.J. and Wiegmans, B. (2007) 'A new hinterland transport concept for the port of Rotterdam: organisational and/or technological challenges', in Proceedings of the Transportation Research Forum, March, North Dakota State University.

\section{Notes}

1 Economies of density imply that the variable cost rises by a rate that is less than proportional with rising output, given a fixed capital stock (Blauwens et al., 2016).

2 There is a new app developed (book-a-lock) to deal specifically with barge lock planning in the port of Antwerp (Meeussen, 2016).

3 In the data file, each line represents a container that is moved from the port of Antwerp to the inland terminal in Hokoken.

4 See for instance [online] https://www.joc.com/port-news/port-antwerp-unveils-its-bargecongestion-action-plan_20180419.html, which clearly indicates the magnitude of the congestion problem and the nature of the impact on chains.

5 Indexed to 2015 values via the average harmonised inflation Europe (HICP) of 2013, 2014 and 2015.

6 The factor $K$ is obtained from Blauwens et al. (2016). The factor $K$ depends on the risk that one is prepared to take to have a stock-out during the lead time. 